\title{
SOCIO-ECONOMIC AND ENVIRONMENTAL CHARACTERISTICS OF PAPUAN CATFISH AT JEFMAN ISLAND (RAJA AMPAT, WEST PAPUA, INDONESIA): A STUDY OF AQUACULTURE POTENTIAL
}

\author{
Sofian Achmad ${ }^{1 *}$, Suhermanto Achmad ${ }^{2}$, Sayuti Mohammad ${ }^{1}$, Saidin ${ }^{1}$ \\ ${ }^{1}$ Sorong Marine and Fisheries Polytechnic, Sorong, West Papua, Indonesia \\ ${ }^{2}$ Karawang Marine and Fisheries Polytechnic, West Karawang, Indonesia \\ *E-mail: achmad.sofian@kkp.go.id
}

\begin{abstract}
The sustainability of fish is crucial as fish is one of the primary sources of protein. The West Papua community consumes catfish for its protein. This study aimed to identify the socioeconomic and environmental characteristics of Papuan Catfish (Plotosidae) from Jefman Island, Raja Ampat, West Papua, Indonesia. The research was conducted September-November 2020. We observed environmental characteristics in Jefman Island and its surrounding. We interviewed related stakeholders such as fishers and fish merchants. Jefman Island fishers and traders sell Papuan Catfish and other fish in the Jembatan Puri Sorong City fish market. Fishers installed sero (set net) in the waters of Jefman Island and Rumbabo Island. The in situ environmental characteristic of Jefman Island waters was as follows: relatively similar temperature between 30.70 to $32.70^{\circ} \mathrm{C}$, Dissolved Oxygen (DO) level between $4.59-5.81 \mathrm{mg} / \mathrm{L}$, and acidity level $(\mathrm{pH})$ is $6.25-8.23$. The catfish Plotosus is a catfish species available in the Bird's Head of West Papua region. Plotosus is found in Sorong and Raja Ampat waters. Papuan catfish have socioeconomic and environmental potential. Therefore, it is necessary to conduct aquaculture development.
\end{abstract}

\section{KEY WORDS}

Catfish, environment, socio-economic conditions, Raja Ampat.

Indonesia is an archipelago country that has thousands of islands and abundant potential resources. These islands have high biodiversity, socioeconomic, and ecological functions. Papua Indonesia is located in the western part of New Guinea. Papua Indonesia has abundant natural wealth and high biodiversity. Papua Indonesia has two provinces, namely West Papua and Papua. The West Papua Province is about $120,777 \mathrm{~km}^{2}$ divided into 12 regencies and one city, including Raja Ampat Regency (BPS Provinsi Papua Barat, 2017). The natural resources and biodiversity of the Raja Ampat Regency are essential assets for regional development. Biodiversity provides ecosystem services. Raja Ampat Regency has an abundant source of animal-based food such as fish (Pal et al., 2018). Good and sustainable management will benefit the island community and improve national welfare.

Fish is one of the primary sources of animal protein for the West Papua coastal community. Based on 2017 socioeconomic survey data, the national fish consumption was $32.36 \mathrm{~kg} / \mathrm{capita} / \mathrm{year}$. On the other hand, West Papua fish consumption was 58.74 $\mathrm{kg} /$ capita/year (BPS 2017). The community relies on captured fisheries and freshwater aquaculture. Catfish is one of the fish species available in the Sorong region. In addition, there are saltwater catfish such as Papuan Catfish (Plotosidae). These fishes are sold in the fish market and consumed by the community.

There are a small number of studies on the socioeconomic and environmental characteristics of saltwater catfish in West Papua. The relationship between socioeconomy and environment may improve assessment and provide detailed information for the decisionmaker (Galanidi et al., 2018). This study aimed to identify the socioeconomic and environmental characteristics of Papuan Catfish (Plotosidae) from Jefman Island Raja Ampat, West Papua, Indonesia. Papuan Catfish (Plotosidae) study aimed to improve the education sector and environmental management, conservation, and sustainability. 


\section{METHODS OF RESEARCH}

The research was conducted from September to November 2020 in Jefman Island, North Salawati District, Raja Ampat Regency, and Sorong City. Jefman Island is located at $0^{\circ} 55^{\prime} 36.21^{\prime \prime}$ South Latitude and 131 ${ }^{\circ} 7^{\prime} 14.15^{\prime \prime}$ East Longitude (Figure 1). We observed the environmental characteristics of Jefman Island waters and its surrounding. We interviewed relevant stakeholders such as fishers and fish traders. The research location covered the area around Jefman Island Raja Ampat and Sorong City. We used Global Positioning System (GPS), camera, and AM200 Aquaread Water Quality. We analyzed primary and secondary data descriptively.

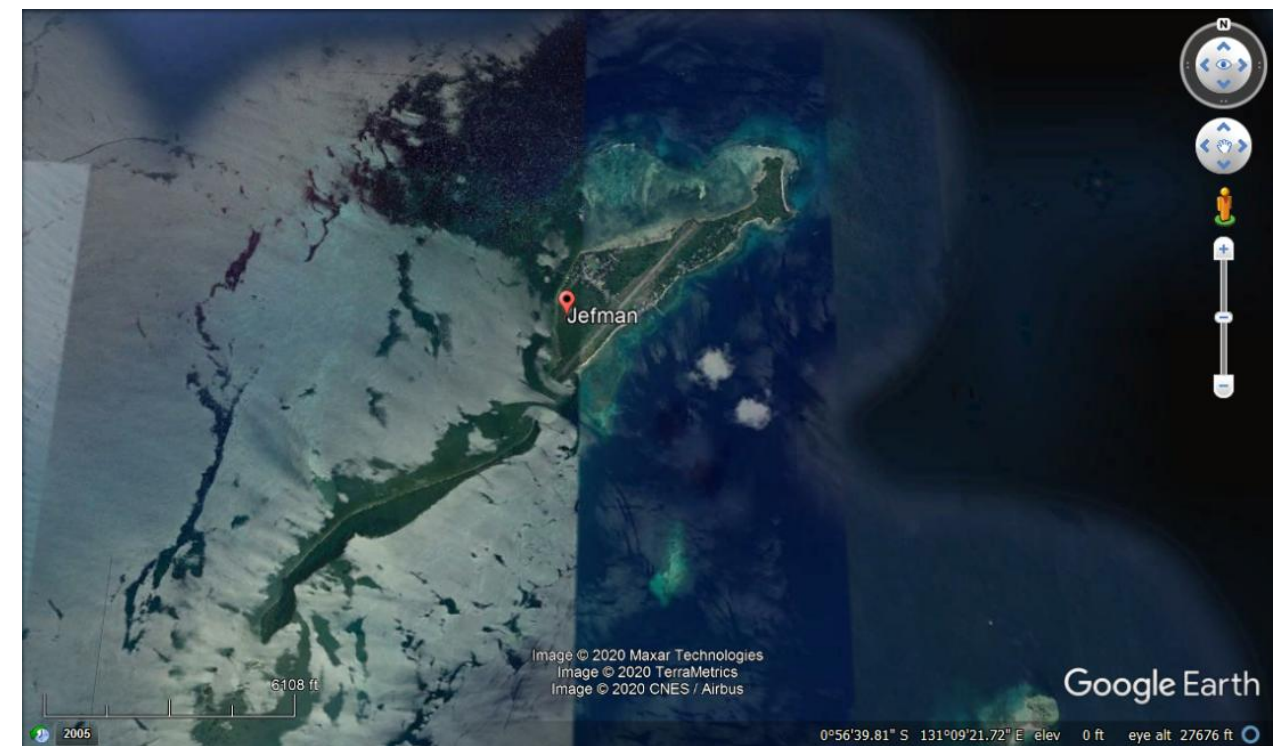

Figure 1 - Map of Jefman Island (Google Earth)

\section{RESULTS AND DISCUSSION}

Raja Ampat Regency is located on the west side of Papua Island and is an expansion of Sorong Regency. Raja Ampat is famous for its high-biodiversity archipelago (Manuputty et al., 2015; Cox and Bright, 2017; Asaad et al., 2018). Wageo, Batanta, Salawati, Misool, and Kofiau Islands are the big islands in Raja Ampat (KKP and USAID 2018). A part of Raja Ampat waters is a marine conservation area. Raja Ampat waters have economic, endemic, and crucial marine biota species (Manuputty et al., 2015). Jefman Island has fisheries potential and historical value. The following figure illustrates Jefman Island and its surrounding waters.

Jefman Island has a land area of $416.42 \mathrm{~km}^{2}$ and is part of the North Salawati District, Raja Ampat Regency (BPS Kab.Raja Ampat 2020). Jefman Island is located in the southern part of Raja Ampat. Jefman Island borders South Batanta District to the north, Sorong City to the east, Central Salawati District to the south, and West Salawati District to the west. Jefman Island is part of the North Salawati District. Jefman Island has two villages, namely Jefman Barat and Jefman Timur. The population of the North Salawati District in 2019 was 3,954 people, with a population density of 9.49 people $/ \mathrm{km}^{2}$. Jefman Barat has 299 families consisting of 976 citizens. Jefman Timur has 174 families consisting of 604 citizens (BPS Kab. Raja Ampat 2020).

Jefman Island was once the center of activities. Visitors traveled to Jefman Island by airplanes. The Jefman Island runway has historical value and is located in the middle part of the island. However, the activity stopped after the runway moved to Domine Eduard Osok airport in Sorong City. The community tends to build houses near the beach. The majority of the community members work as fishers. The activities of Jefman Island fishers are presented in Figure 3. The observation and interview process are shown in Figure 4. 
The Jefman Island waters have marine fishery potentials such as grouper (Epinephelus sp.), rabbitfish (Siganus sp.), stingray (Aetobatus narinari), Lobster (Panulirus sp.), red snapper (Lutjanus campechanus), squid (Loligo sp.) and saltwater catfish. The Jefman Island fishers install sero gear (setnet) in Jefman Island and Rumbabo Island waters. The fishermen installed sero gear in shallow waters, with a 3-5 meter depth at low tide. The fishers catch fish and maintain sero gear daily. Sero gear may catch various fish such as demersal, crustacean, mollusk, Chondrichthyes, and saltwater catfish.

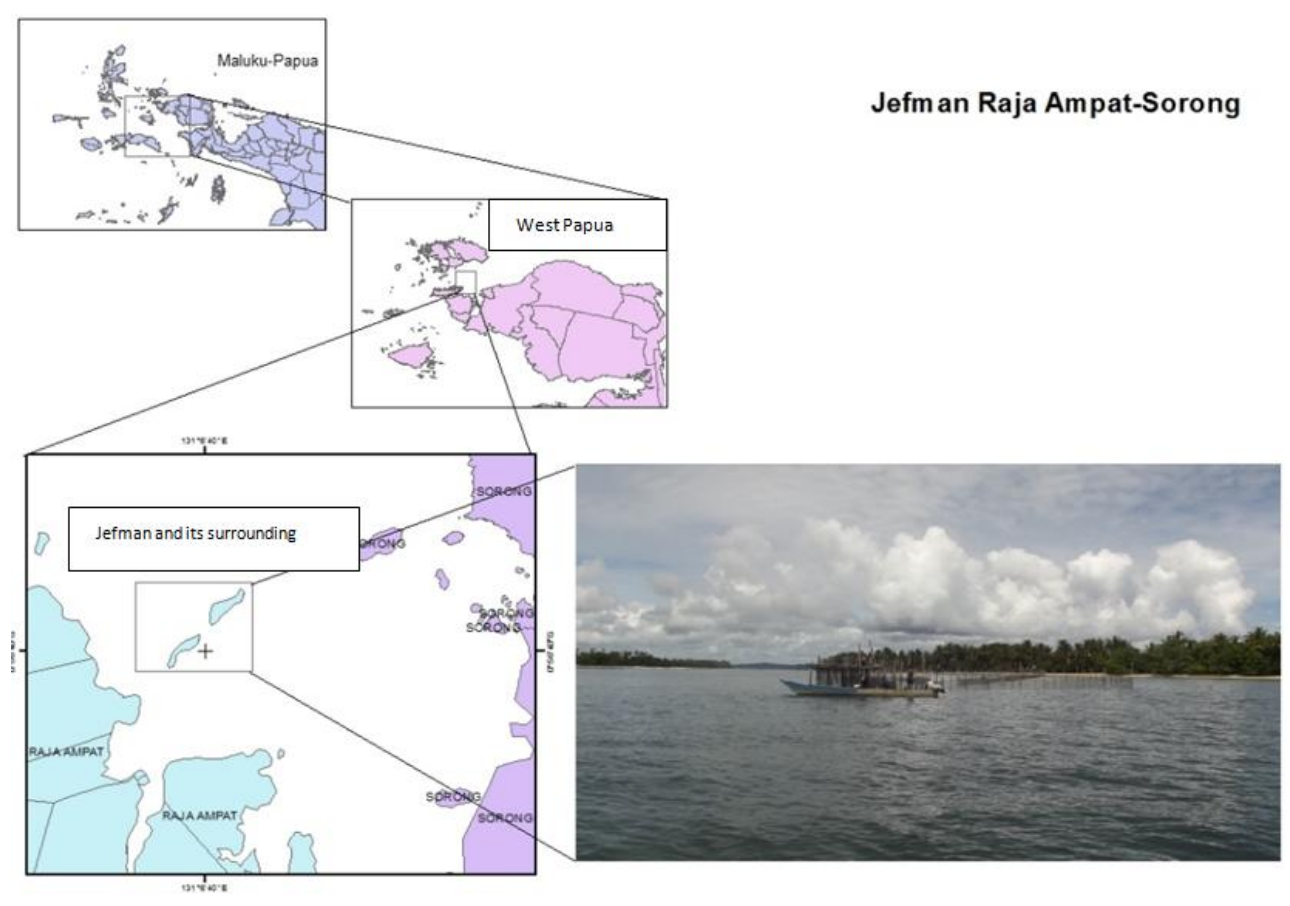

Figure 2 - Waters of Jefman Island

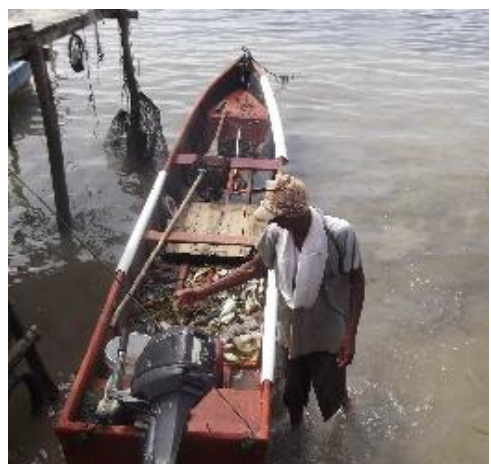

Figure 3 - Fishers of Jefman Island

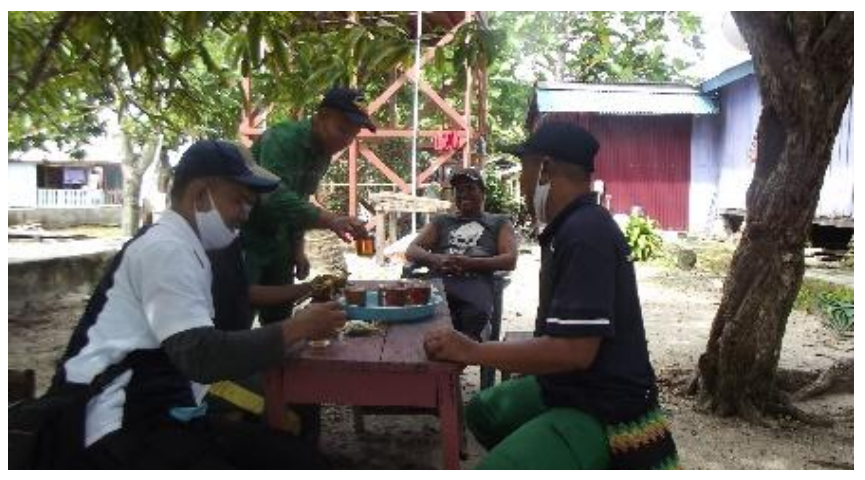

Figure 4 - Observation and Interview with fishers of Jefman Island 
The fishermen gather and sell their catch in Jembatan Puri, the Sorong City fish market. Fish from Jefman Island are traded at the Jembatan Puri fish market by fish traders/fishers from Jefman Island. However, the availability of catfish depends on the season, such as the rainy season. Papuan Catfish is sold in a bundle. Fishers bundle the catfish using a bamboo rope. The fishers and traders sell a bundle of twenty Papuan Catfish for IDR 20,000.00 to 30,000.00. They sell the catch during the weekend due to many visitors. The fish trading activity is illustrated in Figure 5.

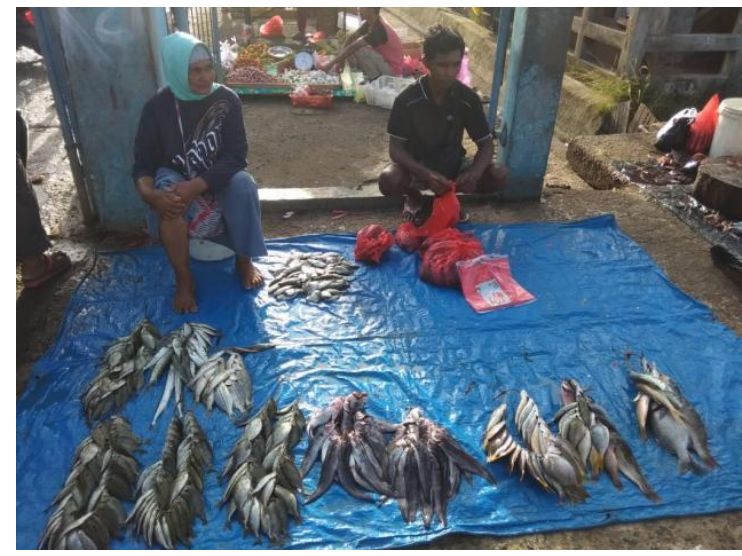

Figure 5 - Jefman Island fish and catfish trader at the Jembatan Puri, Sorong City

The environment is related to socioeconomic characteristics. Damage to the ecosystem may reduce ecosystem goods and services. There is various research using environmental characteristics to determine existing biota. However, the socioeconomic characteristic is equally crucial for stakeholders' decision-making. Plotosus was sold in the Jembatan Puri fish market at certain times. The waters of Sorong and its surrounding is the placed to catching the fish like catfish. Papuan Catfish has economic value as one of the animal-based food sources for the community. Papuan Catfish is available in Jefman Island, Raja Ampat, and Sorong. The anthropogenic pressure in Sorong waters influences the sustainability of Papuan Catfish.

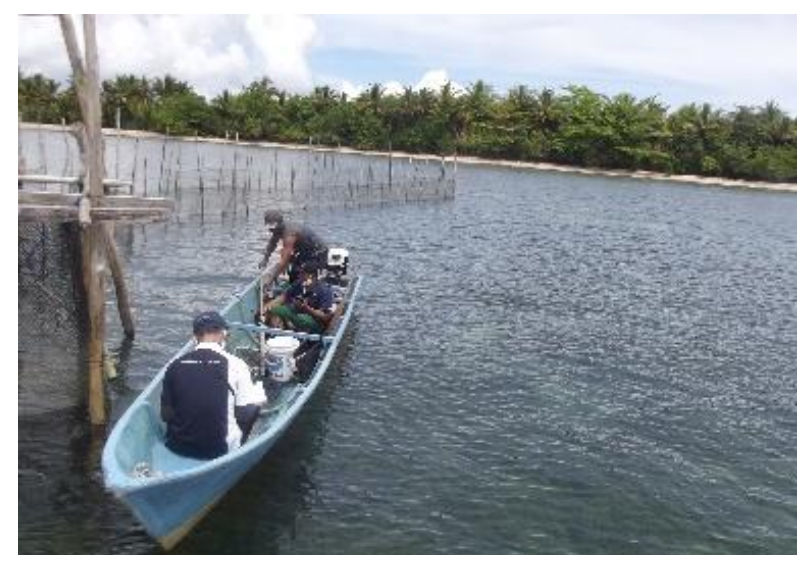

Figure 6 - Environmental Data Collection

The quality of the marine environment influences the distribution of marine biota (Gurning et al., 2019). We performed in situ observation in Jefman Island to determine the marine environmental characteristic. We completed the observation in three posts near the sero (set net) (Figure 6). The measurement result of the marine environmental characteristic of Jefman Island is presented in Table 1.

Water quality is determined by temperature, dissolved oxygen (DO), acidity $(\mathrm{pH})$, salinity, and TDS. Temperature is an essential indicator in determining effects on other water 
parameters (Siburian et al., 2017; Long et al. 2021). The water temperature ranged between 30.70 to $32.70^{\circ} \mathrm{C}$. The temperature range was in normal condition, adhering to the natural temperature conditions of tropical waters $\left(23\right.$ to $\left.32^{\circ} \mathrm{C}\right)$. The temperature range was suitable for organisms to live (Siburian et al., 2017). According to Gurning et al (2019), the bottom of tropical waters should have a water temperature between 22 to $30^{\circ} \mathrm{C}$ (Fishbase). The temperature is suitable for eel-tail catfish (Plotosus canius). Dissolved Oxygen (DO) is crucial for aquatic biota and necessary for respiration, body metabolic processes. Furthermore, DO is essential for the oxidation of organic and inorganic materials in aerobic processes (Gurning et al., 2019). Jefman Island waters have a DO level of $4.59-5.81 \mathrm{mg} / \mathrm{L}$. DO is essential for living organisms. DO fluctuates depending on temperature and salinity (Siburian et al., 2017).

Table 1 - The average measurement result of water quality parameter in Jefman Island waters

\begin{tabular}{llllllll}
\hline Post & Latitude & Longitude & Temperature $\left({ }^{\circ} \mathrm{C}\right)$ & $\mathrm{DO}(\mathrm{mg} / \mathrm{L})$ & Salinity \%o & $\mathrm{pH}$ & TDS $(\mathrm{ppm})$ \\
\hline 1 & $0^{\circ} 55^{\prime} 50^{\prime \prime}$ & $131^{\circ} 7^{\prime} 11^{\prime \prime}$ & 30.70 & 4.59 & 34.34 & 8.23 & 33.88 \\
2 & $0^{\circ} 566^{\prime} 32^{\prime \prime}$ & $131^{\circ} 6{ }^{\prime} 32^{\prime \prime}$ & 30.80 & 5.81 & 31.42 & 7.56 & 32.03 \\
3 & $0^{\circ} 56^{\prime} 53^{\prime \prime}$ & $131^{\circ} 61^{\prime \prime}$ & 32.70 & 5.54 & 28.18 & 6.25 & 28.36 \\
\hline
\end{tabular}

The acidity level $(\mathrm{pH})$ affects marine biota as significant $\mathrm{pH}$ change may affect marine life. Jefman Island had a pH level of 6.25 to 8.23. Therefore, Jefman Island waters adhere to the Minister of Environment Decree Number 51 of 2004 quality standards. The seawater $\mathrm{pH}$ level should range between 7.00 to 8.5. The appropriate $\mathrm{pH}$ level for aquatic life is 6.5 to 8.5 . Therefore, Jefman Island has a good pH level (Siburian et al., 2017). Salinity is crucial in determining marine biota ecosystems. Jefman Island waters have a salinity level of 28.18 to 34.34. Hoek et al (2016) found an average salinity of 29.1 to $30.0 \mathrm{ppt}$ (good) in Jefman Island. The river water may influence the water salinity in the coastline (Siburian et al., 2017). Jefman Island has a TDS value of 28.36 to $33.88 \mathrm{ppm}$. This research was lower than Erari et al., (2012) in the Youtefa Bay, Jayapura, Papua (34.4 ppm). Weathering of rocks, soil runoff, and anthropogenic factors (domestic and industrial waste) influence the TDS level (Rinawati et al., 2016). The measurement result showed that Jefman Island water quality adhered to the quality standards of marine biota.

The marine environmental condition around Jefman Island illustrates the existing ecosystem. Manuputty et al., (2015) analyzed the environmental condition of Jefman Island. Jefman Island community build houses on the beach. Jefman Island seabed is sandy, overgrown with seagrass and coral. Furthermore, the stone coral cover is less than dead coral algae (DCA). Hoek et al., (2016) stated that Jefman Island had 60\% seagrass cover in healthy condition.

The catfish Plotosus is a species that lives in the Bird's Head West Papua region around the waters of Sorong and Raja Ampat (Allen and Erdmann 2009). The distribution of this species covers the Indo-Pacific region (Ali et al., 2017). Their habitat is in coastal waters, reefs, and soft substrates (Edelist et al., 2012). Sea catfish Plotosidae in other parts of Indonesia are the main catch targets, such as in the waters of Kolono Bay, Southeast Sulawesi (Asriyana et al., 2020). Fish stocks and catches can be disrupted by overfishing and pollution of the marine environment (Cámara and Santero-Sánchez 2019). This will have an impact on the environment and socio-economic community.

The socioeconomic and environmental characteristic of Papuan Catfish illustrates the potential of the fishery as an animal-based food source. However, it is necessary to reduce the dependency to capture fisheries by developing aquaculture. The aquaculture sector fulfills global animal protein need. Indonesia also depends on the aquaculture sector to meet animal protein need. Environmentally friendly aquaculture may solve the stagnant production of capture fisheries (Guillen et al., 2019). Aquaculture reduces capture fisheries activity and preserves natural resources (Longo et al., 2019). Improving cultivated produce may increase global food security and nutrient quality (Guillen et al., 2019).

Seafood is a crucial source of nutrition. Seafood provides animal protein for more than 3.1 billion people in 2013 (FAO, 2016). Seafood generally refers to grouper, snapper, shrimp, 
lobster, crab, tuna, etc. However, there is little mention of catfish. Indonesia has the highest production rate of freshwater catfish (Clarias sp.). However, Indonesia has not cultivated saltwater catfish. Irawan and Raza'i (2019) stated that saltwater catfish might be cultivated through crossbreeding eel-tailed catfish and Clarias gariepinus.

Papuan Catfish cultivation development is alternative resource management in Jefman Island. However, it is necessary to pay attention to socioeconomic and environmental conditions. Papuan Catfish cultivation may support community livelihood sustainably. The potential of Jefman Island fisheries (catfish and other types of fish) is both an asset and a challenge. It is necessary to preserve the sustainability of Jefman Island's natural resources.

\section{CONCLUSION}

Papuan Catfish from Jefman Island, Raja Ampat, West Papua, provides ecological and socioeconomic potential in Sorong Raya. The fishers generally install sero (set net) in Jefman Island and Rumbabo Island waters. The marine environmental characteristic in Jefman Island waters is suitable for Papuan Catfish habitat. However, it is necessary to conduct further research on the potential and characteristics of Jefman Island's Papuan Catfish for aquaculture purposes.

\section{REFERENCES}

1. Ali, M., Saad, A., Ali, A. L., \& Capapé, C (2017). Additional records of striped eel catfish Plotosus lineatus (Osteichthyes: Plotosidae) from the Syrian Coast (Eastern Mediterranean). Thalassia Salentina, 39, 3-8.

2. Allen, G. R., \& Erdmann, M. V (2009). Reef fishes of the bird's head peninsula, West Papua, Indonesia. Check list, 5(3), 587-628.

3. Armbruster JW. 2011. Global Catfish Biodiversity. Am. Fish. Soc. Symp.:15-37.

4. Asaad, I., Lundquist, C. J., Erdmann, M. V., \& Costello, M. J (2018). Delineating priority areas for marine biodiversity conservation in the Coral Triangle. Biological Conservation, 222, 198-211.

5. Asriyana, A., Halili, H., \& Irawati, N. Komposisi By-catch Perikanan Lele Laut (Famili Plotosidae) di Perairan Teluk Kolono, Sulawesi Tenggara. JSIPi (Jurnal Sains and Inovasi Perikanan) (Journal of Fishery Science and Innovation), 4(1), 1-11.

6. BPS Provinsi Papua Barat [Badan Pusat Statistik Provinsi Papua Barat] (2017). Provinsi Papua Barat Dalam Angka 2017. Manokwari: BPS Provinsi Papua Barat.

7. BPS Raja Ampat [Badan Pusat Statistik Raja Ampat]. 2020. Distrik Salawati Utara Dalam Angka. Badan Pusat Statistik Kabupaten Raja Ampat.

8. BPS RI [Badan Pusat Statistik]. 2017. Kajian Konsumsi Bahan Pokok Tahun 2017. Badan Pusat Statistik Republik Indonesia.

9. Cámara, A., \& Santero-Sanchez, R (2019). Economic, Social, and Environmental Impact of a Sustainable Fisheries Model in Spain. Sustainability, 11(22), 6311.

10. $\mathrm{Cl}$ [Conservation International] (2015). West Papua as Conservation Province. [pdf] Tersedia di:https://conservation.org/publications/Documents/CI_SLP-West-PapuaConservation-Province.pdf [Diakses pada 17 Apr. 2018].

11. Cox, K., \& Bright, J (2017). Raja Ampat: A Biodiversity Hot Spot and the Future of Marine Conservation. Fisheries, 42(9), 462-467.

12. DJPDSPKP [Direktorat Jenderal Penguatan Daya Saing Produk Kelautan and Perikanan Kementerian Kelautan and Perikanan]. 2020. Statistik Ekspor Hasil Perikanan Tahun 2015-2019 Provinsi Papua Barat.

13. Edelist, D., Golani, D., Rilov, G., \& Spanier, E (2012). The invasive venomous striped eel catfish Plotosus lineatus in the Levant: possible mechanisms facilitating its rapid invasional success. Marine Biology, 159(2), 283-290.

14. Erari, S. S., Mangimbulude, J., \& Lewerissa, K (2012). Pencemaran Organik di Perairan Pesisir Pantai Teluk Youtefa Kota Jayapura, Papua. In Prosiding Seminar Nasional Kimia Unesa (pp. 327-340). 
15. FAO [Food and Agriculture Organization of the United Nations]. 2016. The State of World Fisheries and Aquaculture 2016. Contributing to food security and nutrition for all. FAO, Rome. 200 pp.

16. Galanidi M, Zenetos A, Bacher S. 2018. Assessing the socio-economic impacts of priority marine invasive fishes in the Mediterranean with the newly proposed SEICAT methodology. Medit. Mar. Sci., 19/1, 2018, 107-123

17. Guillen, J., Natale, F., Carvalho, N., Casey, J., Hofherr, J., Druon, J. N., Fiore, G., Gibin, M., Zanzi, A., \& Martinsohn, J. T (2019). Global seafood consumption footprint. Ambio, 48(2), 111-122.

18. Gurning, R.V., Susiana S, Suryanti A. 2019. Pertumbuhan and status eksploitasi ikan sembilang (Plotosus canius) di perairan Kota Tanjung Pinang Kepulauan Riau. Jurnal Akuakultur, Pesisir and Pulau Pulau Kecil (EISSN 2598-8298) Vol. 3 No. 2: 63-72, November 2019.

19. Hoek, F., Razak, A., Hamid, H., Muhfizar, M., Suruwaky, A. M., Ulat, M. A., ... \& Arfah, A (2016). Struktur Komunitas Lamun di Perairan Distrik Salawati Utara Kabupaten Raja Ampat. Jurnal Airaha, 5(1), 087-095.

20. Irawan, H., Raza'i T.S. 2019. Potensi hibridisasi antara ikan lele dumbo Clarias gariepinus sembilang Plotosus canius. Intek Akuakultur 3(1):139-148.

21. Iswanto B, Suprapto R, Marnis H. 2016. Morphological characteristics of a red strain of the egyptian african catfish (Clarias gariepinus Burchell 1822). 11(2):49-59

22. Kementerian Kelautan and Perikanan Republik Indonesia and Proyek Sustainable Ecosystems Advanced (SEA) USAID. 2018. Kondisi Laut: Indonesia, Jilid Tiga: Menjelajahi Indonesia bagian Timur: Proyek SEA USAID - Lokasi and Kegiatan. Jakarta, Indonesia.

23. Keong, C.Y., 2015. Sustainable resource management and ecological conservation of mega-biodiversity: the Southeast Asian Big-3 reality. International Journal of Environmental Science and Development, 6(11), 876.

24. Long, C. A., Chabot, R. M., El-Khazen, M. N., Kelley, J. R., Mollet-Saint Benoît, C., \& Mansfield, K. L (2021). Incongruent long-term trends of a marine consumer and primary producers in a habitat affected by nutrient pollution. Ecosphere, 12(6), e03553.

25. Longo, S. B., Clark, B., York, R., \& Jorgenson, A. K (2019). Aquaculture and the displacement of fisheries captures. Conservation Biology, 33(4), 832-841.

26. Manuputty AEW, Souhoka J, Hukom FD, Cappenberg HAW, Sihaloho HF, Widyastuti E, Irawan A, Limbong SR, Salatalohy A, Picasouw J, Anggraeni K, Arifin A. 2015. Studi Baseline Kesehatan Terumbu Karang and Ekosistem Terkait di Perairan Pulau Salawati and Pulau Batanta Kabupaten Radja Ampat, Papua Barat. Coremap CTI Pusat Penelitian Oseanografi Lembaga IImu Pengetahuan Indonesia. Jakarta : COREMAP CTI LIPI 2015

27. Pal, J., Shukla, B. N., Maurya, A. K., Verma, H. O., Pandey, G., \& Amitha, A (2018). A review on role of fish in human nutrition with special emphasis to essential fatty acid. International Journal of Fisheries and Aquatic Studies, 6(2), 427-430.

28. Rinawati, Hidayat, D., Suprianto, R., \& Dewi, P. S (2016). Penentuan kandungan zat padat (total dissolve solid and total suspended solid) di perairan Teluk Lampung. Analit: Analytical and Environmental Chemistry, 1(1).

29. Siburian, R., Simatupang, L., \& Bukit, M (2017). Analisis kualitas perairan laut terhadap aktivitas di lingkungan pelabuhan Waingapu-Alor Sumba Timur. Jurnal Pengabdian Kepada Masyarakat, 23(1), 225-232.

30. Soedarmo, Sri Puryono Karto. 2018. Mengelola Laut untuk Kesejahteraan Rakyat Refleksi untuk Indonesia Sejahtera. Undip Press

31. Widati AW. 2015. Ketersediaan Pangan Di Provinsi Papua Barat. Prosiding Seminar Nasional Dies Natalis XXXIII Universitas Islam Batik Surakarta. ISBN : 978-979-123035-3. 